\title{
A synthesis of magnetostratigraphic results from Pliocene-Pleistocene sediments cored using the hydraulic piston corer
}

\author{
Bradford M. Clement \\ Department of Geology, Florida International University, Miami
}

Dennis V. Kent

Lamont-Doherty Earth Observatory, Columbia University, Palisades, New York

Neil D. Opdyke

Department of Geology, University of Florida, Gainesville

\begin{abstract}
We present a summary evaluation of the distribution and qualitative ranking of the Plio-Pleistocene magnetostratigraphic results obtained to date from Deep Sea Drilling Project and Ocean Drilling Program piston-cored sites. A review of the published magnetostratigraphic records provides insights into the important extrinsic and intrinsic factors which affect the quality of the paleomagnetic records. The extrinsic factors originate with drilling processes, such as core barrel remagnetization, and steps can be taken to reduce these effects and improve the data quality. The distribution of the high-quality records correlates well both with areas of terrigenous sediment input as well as regions of moderate biological productivity. This suggests that important intrinsic factors include the origin of the original magnetic carrier in the sediment (lithogenic or biogenic) and the degree to which the magnetic carrier has been affected by reduction diagenesis.
\end{abstract}

\section{Introduction}

The hydraulic piston corer (HPC) and the advanced hydraulic piston corer (APC) recover thick sequences of mechanically undisturbed deep-sea sediment which are ideal for paleomagnetic study. Since the first use of the hydraulic piston corer on Deep Sea Drilling Project (DSDP) Leg 64, magnetostratigraphy has played an increasingly important role in many of the biostratigraphic and paleoceanographic objectives of both the DSDP and the Ocean Drilling Program (ODP). In addition, deep-sea sediment cores have proven to be a valuable source of information regarding the variation of Earth's magnetic field. On November 7-8, 1994, 30 paleomagnetists met at a Joint Oceanographic Institution/US Science Advisory Committee sponsored workshop on polarity reversal transitions to discuss how to obtain better records of geomagnetic field behavior from ODP cores. The workshop participants advocated obtaining a broader geographic distribution of geomagnetic field behavior records (1) by sampling existing cores that provide high resolution records and (2) by proposing new drill sites to obtain additional high-quality records.

In spite of the importance of magnetostratigraphy in ODP objectives, it has proven difficult to predict the success of

Copyright 1996 by the American Geophysical Union.

Paper number 95PA03524.

0883-8305/96/95PA-03524\$12.00 magnetostratigraphic studies at a given site, particularly at depths below a few tens of meters subbottom. In order to aid in planning new drilling programs, it is important to try to understand where the high-quality records have been obtained and what the important factors are that affect the quality of the records. These were our objectives in reviewing the magnetostratigraphic results obtained from sediments cored using the HPC or APC. We present here a summary evaluation of the distribution and qualitative ranking of the PliocenePleistocene magnetostratigraphic results obtained to date from DSDP and ODP HPC/APC cored sites.

We surveyed the Pliocene-Pleistocene magnetostratigraphic results published in the Initial Reports or Scientific Results volumes of DSDP Legs 64-96 and ODP Legs 100-133, the extent of the published records available to date. We also included results from ODP Legs 138 and 145 for which only the data presented in the site reports were available. This survey was limited to the Pliocene -Pleistocene sediments in part because we are primarily interested in examining high resolution, high-fidelity records. High-resolution paleomagnetic records have recently yielded exciting results regarding not only polarity transitions but also secular variation and paleointensity variations in the geomagnetic field. Also, the uncertainties in the biostratigraphic constraints that might affect the correlation of observed polarity zonations with the geomagnetic polarity timescale (GPTS) are minimal within the Pliocene-Pleistocene. In addition, magnetostratigraphic results from this time interval are more numerous and from a greater geographical distribution than 


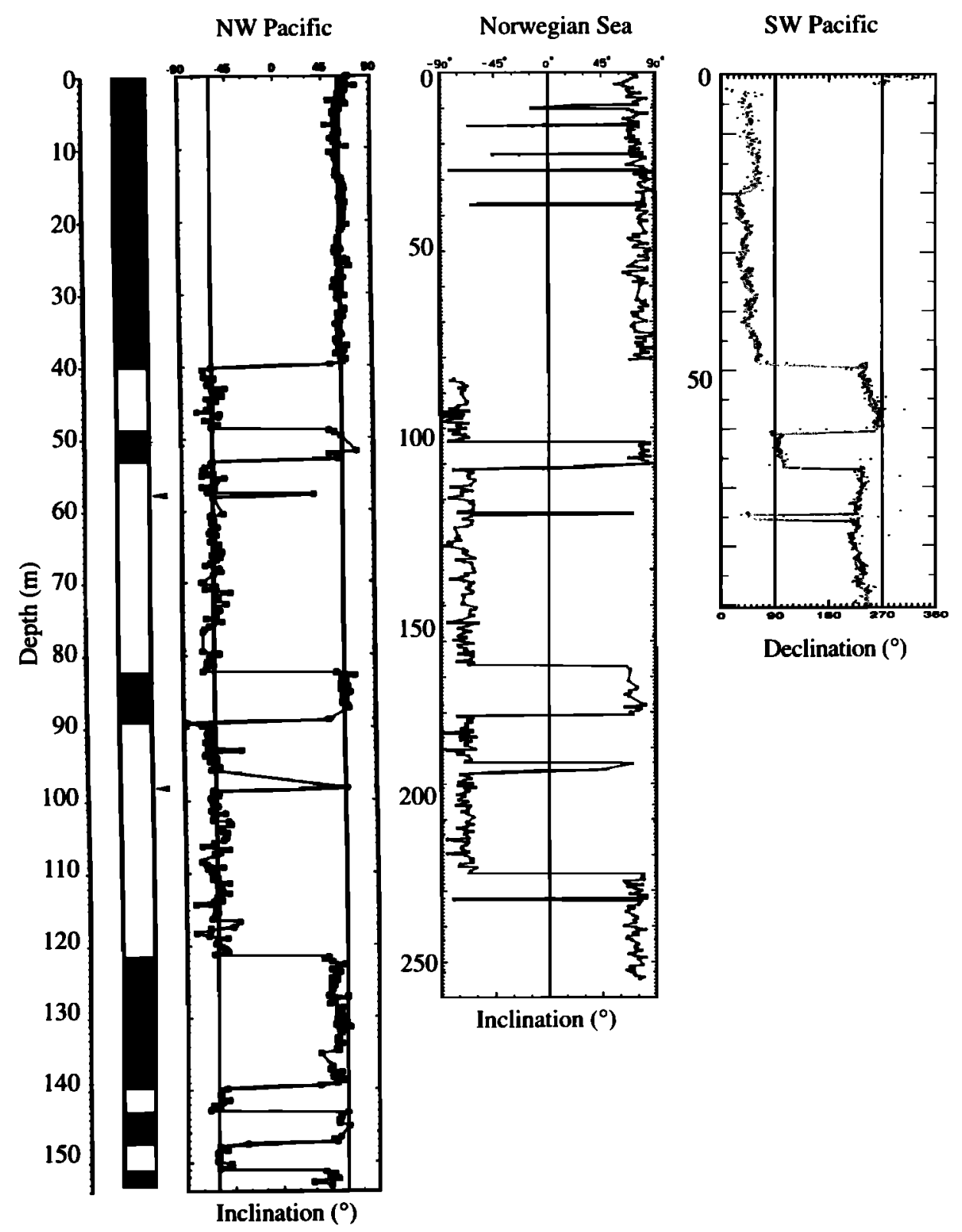

Figure 1. Examples of category 1 magnetostratigraphic records obtained from Deep Sea Drilling Project (DSDP) Site 580 in the NW Pacific, Ocean Drilling Program (ODP) Site 644 in the Norwegian Sea, and ODP Site 767 from the SW Pacific.

older records. Shipboard laboratory techniques and methods are generally standardized so that the differences in quality between records most likely originate in factors intrinsic to the sediment and the recording process and are not the result of different laboratory approaches.

The objective of this survey was to identify those sediments which are high fidelity records of polarity history. Therefore the following criteria were used to qualitatively rank the magnetostratigraphic records:

Category 1 records exhibit clear antipodal, normal, and reverse polarity records in which the directions are close to the expected geocentric axial dipole (GAD) directions without excessive scatter. The polarity zones allow an unambiguous correlation with the geomagnetic polarity timescale. Examples of category 1 records include Sites 580 in the northwest Pacific, 664 in the Norwegian Sea, and 767 from the southwestern Pacific (Figure 1) . Category 1 sites are listed in Table 1.

Category 2 records exhibit nearly antipodal, normal and reverse polarity directions; however, the correlation with the GPTS is complicated by core recovery problems or coring disturbance. These sites would be worth drilling again to obtain a high-fidelity magnetostratigraphic record. Category 2 sites are listed in Table 1.

In Category 3 records, both polarities appear to have been recorded; however, unusually large amounts of scatter cause an 
Table 1. Locations of Category 1 - 5 Sites

Site Leg Lat.. Long. Category* Reference

\begin{tabular}{|c|c|c|c|c|c|}
\hline 480 & 64 & 27.90 & -111.65 & 1 & Karlin and Levi [1982] \\
\hline 502 & 68 & 11.49 & -79.38 & 1 & Kent and Spariosu [1982a] \\
\hline 503 & 68 & 4.05 & -95.64 & 1 & Kent and Spariosu [1982b] \\
\hline 513 & 71 & -47.58 & -24.64 & 1 & Salloway [1984] \\
\hline 514 & 71 & -46.00 & -26.90 & 5 & Salloway [1984] \\
\hline 519 & 73 & -26.13 & -11.65 & 5 & Tauxe et al. [1984] \\
\hline 521 & 73 & -26.07 & -10.26 & 3 & Tauxe et al. [1984] \\
\hline 522 & 73 & -26.11 & -5.13 & 3 & Tauxe et al. [1984] \\
\hline 548 & 80 & 48.00 & -12.00 & 4 & Townsend $[1985]$ \\
\hline 552 & 81 & 56.00 & -13.00 & 1 & Krumsiek and Roberts [1984] \\
\hline 571 & 85 & 3.99 & -114.05 & 4 & Weinreich and Theyer [1985] \\
\hline 572 & 85 & 1.50 & -113.90 & 5 & Weinreich and Theyer [1985] \\
\hline 573 & 85 & 0.50 & -133.30 & 1 & Weinreich and Theyer [1985] \\
\hline 574 & 85 & 4.13 & -133.31 & 2 & Weinreich and Theyer [1985] \\
\hline 575 & 85 & 5.90 & -135.02 & 2 & Weinreich and Theyer [1985] \\
\hline 577 & 86 & 32.44 & 157.81 & 1 & Bleil $[1986]$ \\
\hline 579 & 86 & 38.58 & 153.51 & 1 & Bleil $[1986]$ \\
\hline 580 & 86 & 41.62 & 153.97 & 1 & Bleil [1986] \\
\hline 586 & 90 & 0.49 & 158.49 & 5 & Barton and Bloemendal [1986] \\
\hline 587 & 90 & -21.18 & 161.33 & 5 & Barton and Bloemendal [1986] \\
\hline 588 & 90 & -26.11 & 161.23 & 4 & Barton and Bloemendal [1986] \\
\hline 589 & 90 & -30.71 & 163.50 & 3 & Barton and Bloemendal [1986] \\
\hline 590 & 90 & -30.16 & 163.35 & 5 & Barton and Bloemendal [1986] \\
\hline 591 & 90 & -31.58 & 164.44 & 5 & Barton and Bloemendal [1986] \\
\hline 592 & 90 & -36.47 & 165.44 & 5 & Barton and Bloemendal [1986] \\
\hline 594 & 90 & -40.50 & 167.67 & 5 & Barton and Bloemendal [1986] \\
\hline 606 & 94 & 37.33 & -35.50 & 1 & Clement and Robinson [1985] \\
\hline 607 & 94 & 41.00 & -32.90 & 1 & Clement and Robinson [1985] \\
\hline 608 & 94 & 45.84 & -23.09 & 1 & Clement and Robinson [1985] \\
\hline 609 & 94 & 49.86 & -24.23 & 1 & Clement and Robinson [1985] \\
\hline 610 & 94 & 53.21 & -18.80 & 1 & Clement and Robinson [1985] \\
\hline 611 & 94 & 52.84 & -30.26 & 1 & Clement and Robinson [1985] \\
\hline 626 & 101 & 25.59 & -79.54 & 5 & Sager [1988] \\
\hline 629 & 101 & 27.40 & -78.36 & 5 & Sager [1988] \\
\hline 630 & 101 & 27.44 & -78.34 & 5 & Sager [1988] \\
\hline 631 & 101 & 23.58 & -75.74 & 5 & Sager [1988] \\
\hline 633 & 101 & 23.68 & -75.62 & 3 & Sager [1988] \\
\hline 642 & 104 & 67.22 & 2.93 & 1 & Bleil [1989] \\
\hline 644 & 104 & 66.68 & 4.58 & 1 & Bleil [1989] \\
\hline 646 & 105 & 58.21 & -48.37 & 1 & Clement et al. [1989] \\
\hline 647 & 105 & 53.33 & -45.26 & 3 & Clement et al. [1989] \\
\hline 650 & 107 & 39.36 & 13.90 & 3 & Channell et al. [1990] \\
\hline 653 & 107 & 40.26 & 11.44 & 5 & Channell et al. [1990] \\
\hline 655 & 107 & 40.18 & 12.46 & 5 & Channell et al. [1990] \\
\hline 657 & 108 & 21.33 & -20.95 & 4 & Tauxe et al. [1989] \\
\hline 658 & 108 & 20.75 & -18.58 & 1 & Tauxe et al. [1989] \\
\hline 659 & 108 & 18.08 & -21.03 & 3 & Tauxe et al. [1989] \\
\hline 660 & 108 & 10.01 & -19.25 & 1 & Tauxe et al. [1989] \\
\hline 661 & 108 & 9.45 & -19.39 & 4 & Tauxe et al. [1989] \\
\hline 662 & 108 & -1.39 & -11.73 & 5 & Tauxe et al. [1989] \\
\hline 663 & 108 & -1.19 & -11.87 & 5 & Tauxe et al. [1989] \\
\hline 664 & 108 & 0.11 & -23.23 & 2 & Tauxe et al. [1989] \\
\hline 665 & 108 & 2.95 & -19.67 & 1 & Tauxe et al. [1989] \\
\hline 666 & 108 & 3.50 & -20.17 & 3 & Tauxe et al. [1989] \\
\hline 667 & 108 & 4.57 & -21.91 & 4 & Tauxe et al. [1989] \\
\hline 668 & 108 & 4.77 & -20.93 & 4 & Tauxe et al. [1989] \\
\hline 671 & 110 & 15.52 & -58.73 & 5 & Hounslow et al. [1990] \\
\hline 672 & 110 & 15.54 & -58.64 & 5 & Hounslow et al. [1990] \\
\hline 673 & 110 & 15.53 & -58.72 & 5 & Hounslow et al. [1990] \\
\hline 674 & 110 & 15.53 & -58.85 & 5 & Hounslow et al. [1990] \\
\hline 675 & 110 & 15.52 & -58.71 & 5 & Hounslow et al. [1990] \\
\hline 676 & 110 & 15.53 & -58.70 & 5 & Hounslow et al. [1990] \\
\hline 677 & 111 & 1.20 & -83.73 & 5 & Becker et al. [1988] \\
\hline 678 & 111 & 1.21 & -83.72 & 5 & Becker et al. [1988] \\
\hline 679 & 112 & -11.06 & -78.27 & 4 & Suess et al. [1988] \\
\hline 680 & 112 & -11.06 & -78.08 & 4 & Suess et al. [1988] \\
\hline 681 & 112 & -10.98 & -77.96 & 4 & Suess et al. [1988] \\
\hline
\end{tabular}

Table 1. (continued)

Site Leg Lat.. Long. Category* Reference

\begin{tabular}{|c|c|c|c|c|c|}
\hline 480 & 64 & 27.90 & -111.65 & 1 & Karlin and Levi [1982] \\
\hline 682 & 112 & -11.27 & -79.06 & 4 & Suess et al. [1988] \\
\hline 683 & 112 & -9.03 & -80.41 & 4 & Suess et al. [1988] \\
\hline 684 & 112 & -8.99 & -79.91 & 4 & Suess et al. [1988] \\
\hline 685 & 112 & -9.11 & -80.58 & 4 & Suess et al. [1988] \\
\hline 686 & 112 & -13.48 & -76.89 & 4 & Suess et al. [1988] \\
\hline 687 & 112 & -12.86 & -76.99 & 4 & Suess et al. [1988] \\
\hline 688 & 112 & -11.54 & -78.94 & 4 & Suess et al. [1988] \\
\hline 689 & 113 & -64.52 & 3.10 & 3 & Speil [1990] \\
\hline 690 & 113 & -65.16 & 1.20 & 3 & Speil [1990] \\
\hline 701 & 114 & -51.98 & -23.21 & 3 & Clement and Hailwood [1991] \\
\hline 704 & 114 & -46.88 & 7.42 & 3 & Hailwood and Clement [1991b] \\
\hline 709 & 115 & -3.91 & 60.55 & 3 & Schneider and Kent [1990] \\
\hline 710 & 115 & -4.31 & 60.98 & 2 & Schneider and Kent [1990] \\
\hline 711 & 115 & -2.74 & 61.16 & 2 & Schneider and Kent [1990] \\
\hline 714 & 115 & 5.06 & 73.79 & 4 & Schneider and Kent [1990] \\
\hline 716 & 115 & 4.93 & 73.28 & 4 & Schneider and Kent [1990] \\
\hline 717 & 116 & -0.93 & 81.39 & 4 & Hall and Sager [1990] \\
\hline 721 & 117 & 16.68 & 59.86 & 3 & Hayashida and Bloemendal [1991] \\
\hline 722 & 117 & 16.62 & 59.80 & 3 & Hayashida and Bloemendal [1991] \\
\hline 723 & 117 & 18.05 & 57.61 & 4 & Hayashida and Bloemendal [1991] \\
\hline 724 & 117 & 18.46 & 57.79 & 4 & Hayashida and Bloemendal [1991] \\
\hline 725 & 117 & 18.49 & 57.70 & 4 & Hayashida and Bloemendal [1991] \\
\hline 726 & 117 & 17.82 & 57.37 & 4 & Hayashida and Bloemendal [1991] \\
\hline 727 & 117 & 17.77 & 57.59 & 3 & Hayashida and Bloemendal [1991] \\
\hline 728 & 117 & 17.68 & 57.83 & 3 & Hayashida and Bloemendal [1991] \\
\hline 730 & 117 & 17.73 & 57.69 & 4 & Hayashida and Bloemendal [1991] \\
\hline 731 & 117 & 16.47 & 59.70 & 3 & Hayashida and Bloemendal [1991] \\
\hline 737 & 119 & -50.23 & 73.03 & 3 & Sakai and Keating [1991] \\
\hline 745 & 119 & -59.59 & 85.85 & 1 & Sakai and Keating [1991] \\
\hline 747 & 120 & -54.81 & 76.79 & 4 & Heider et al. [1992] \\
\hline 748 & 120 & -58.44 & 79.00 & 4 & Inokuchi and Heider [1992] \\
\hline 751 & 120 & -57.73 & 79.81 & 4 & Heider et al. [1992] \\
\hline 758 & 121 & 5.38 & 90.36 & 1 & Pearce et al., 1989] \\
\hline 762 & 122 & -19.89 & 112.25 & 4 & Tang [1992] \\
\hline
\end{tabular}

$\begin{array}{ll}122 & -19.89\end{array}$

$\begin{array}{lll}763 & 122 & -20.59\end{array}$

$\begin{array}{lll}767 & 124 & 4.79\end{array}$

$\begin{array}{lll}768 & 124 & 8.0^{\wedge}\end{array}$

$\begin{array}{lll}769 & 124 & 8.79\end{array}$

$\begin{array}{lll}782 & 125 & 30.86\end{array}$

$\begin{array}{lll}786 & 125 & 31.87\end{array}$

$\begin{array}{lll}792 & 126 & 32.40\end{array}$

$\begin{array}{lll}793 & 126 & 31.11\end{array}$

$\begin{array}{lll}798 & 128 & 37.04\end{array}$

$\begin{array}{lll}799 & 128 & 39.22\end{array}$

$\begin{array}{lll}803 & 130 & 2.43\end{array}$

$\begin{array}{lll}805 & 130 & 1.23\end{array}$

$\begin{array}{lll}812 & 133 & -17.81\end{array}$

$\begin{array}{lll}813 & 133 & -17.83\end{array}$

$\begin{array}{lll}814 & 133 & -17.83\end{array}$

$\begin{array}{llll}832 & 134 & -14.80\end{array}$

$\begin{array}{llll}833 & 134 & -14.88\end{array}$

$\begin{array}{llll}834 & 135 & -18.57\end{array}$

$\begin{array}{llll}835 & 135 & -18.50 & -177.30\end{array}$

$\begin{array}{lllll}836 & 135 & -20.14 & -176.50\end{array}$

$\begin{array}{lllll}837 & 135 & -20.22 & -176.82\end{array}$

$\begin{array}{lllll}838 & 135 & -20.83 & -176.89\end{array}$

$\begin{array}{lllll}839 & 135 & -20.71 & -176.77\end{array}$

$\begin{array}{llll}840 & 135 & -22.22 & -175.75\end{array}$

$\begin{array}{llll}841 & 135 & -23.35 & -175.30\end{array}$

$\begin{array}{llrr}844 & 138 & 7.92 & -90.48\end{array}$

$\begin{array}{llll}845 & 138 & 9.58 & -94.59\end{array}$

$\begin{array}{llll}846 & 138 & -3.09 & -90.81\end{array}$

$\begin{array}{llll}847 & 138 & 0.19 & -95.32\end{array}$

$\begin{array}{llll}848 & 138 & -2.99 & -110.48\end{array}$

$\begin{array}{llll}849 & 138 & 0.18 & -110.52\end{array}$

$\begin{array}{llll}850 & 138 & 1.30 & -110.52\end{array}$
2]

Hsu et al. [1991]

Hsu et al. [1991]

Hsu et al. [1991]

Ali et al. [1992]

Ali et al. [1992]

Cisowski and Koyama [1992]

Hamano et al. [1992]

Hamano et al. [1992]

Gallet et al. [1993]

Gallet et al. [1993]

McNeill et al. [1993]

McNeill et al. [1993]

McNeill et al. [1993]

Zhao et al. [1994]

Zhao et al. [1994]

Abrahamsen and Sager [1994]

Abrahamsen and Sager [1994]

Abrahamsen and Sager [1994]

Abrahamsen and Sager [1994]

Abrahamsen and Sager [1994]

Abrahamsen and Sager [1994]

Abrahamsen and Sager [1994]

Abrahamsen and Sager [1994]

Mayer et al. [1992]

Mayer et al.[1992]

Mayer et al. [1992]

Mayer et al. [1992]

Mayer et al. [1992]

Mayer et al. [1992]

Mayer et al. [1992]
Cisowski and Koyama [1992] 
Table 1. (continued)

\begin{tabular}{rrrrll}
\hline Site & Leg & \multicolumn{2}{l}{ Lat.. } & \multicolumn{3}{l}{ Long. Category* Reference } \\
\hline 851 & 138 & 2.77 & -110.57 & 1 & Mayer et al. $[1992]$ \\
852 & 138 & 5.29 & -110.08 & 1 & Mayer et al. $[1992]$ \\
853 & 138 & 7.21 & -109.75 & 1 & Mayer et al. $[1992]$ \\
854 & 138 & 11.22 & -109.59 & 1 & Mayer et al. $[1992]$ \\
881 & 145 & 47.10 & 161.49 & 2 & Rea et al. $[1993]$ \\
882 & 145 & 50.36 & 167.60 & 2 & Rea et al. $[1993]$ \\
883 & 145 & 51.20 & 167.77 & 2 & Rea et al. $[1993]$ \\
884 & 145 & 51.45 & 168.34 & 1 & Rea et al. $[1993]$ \\
885 & 145 & 44.69 & -168.27 & 2 & Rea et al. $[1993]$ \\
886 & 145 & 44.69 & -168.24 & 2 & Rea et al. $[1993]$ \\
887 & 145 & 54.37 & -148.45 & 1 & Rea et al. $[1993]$ \\
\hline
\end{tabular}

* Category 1, clearly antipodal, normal and reverse polarity directions are observed which may be correlated with the geomagnetic polarity timescale unambiguously; category 2 , nearly antipodal normal and reverse polarity directions are observed but the correlation with the timescale is complicated by core recovery or other extrinsic problems; category 3, Both polarities appear to be recorded, but unusually large amounts of scatter cause an ambiguous correlation with the timescale; category 4 , coherent and apparently stable magnetizations are observed: however, the scatter is too great to allow a correlation with the timescale; category 5 , sediment magnetizations are at or below the instrumental noise level. Note that we have only included sites where the shipboard scientists have reported very weak magnetizations. More category 5 sites probably exist, but due to the weak signal, the data were not reported.

ambiguous correlation with the GPTS. The category 3 sites are listed in Table 1. An example of such a record is shown in Figure 2 obtained from Site 722 on the Owen Ridge. Zones of opposite polarity can be defined, however, short polarity chrons can not be identified and the correlation with the GPTS is difficult at best.

In some cases (category 4) the sediment exhibits a coherent and apparently stable remanent magnetization, however, the dispersion is too great to allow a polarity assignment. The directional records from these sites cannot be interpreted in terms of polarity. Category 4 sites are listed in Table 1.

Category 5 records differ from Category 4 in that the magnetizations are at or below the instrumental noise level and therefore no interpretable magnetization exists.

\section{Factors Affecting the Quality of Magnetostratigraphic Records}

Magnetostratigraphic records ranking 1, 2, and 3 were obtained from 77 out of more than 200 sites cored by DSDP and ODP using the APC. This is a significant underestimate of the success rate because we have not attempted to account for coring at sites where recovery of Plio-Pleistocene pelagic sedimentation was not an objective. A significant number of sites were located to address tectonic or geochemical objectives, and it is clear that drilling into deformed sediments of accretionary prisms or in hydrothermal systems associated with mid-ocean ridges will not recover the type of material suitable for polarity stratigraphy. The percentage of successful magnetostratigraphic results increases dramatically when only sites located in areas of pelagic deposition are considered.
Category 1 and 2 sites often exhibit remarkable records which clearly document the history of the polarity of the geomagnetic field. One of the most important advances made by DSDP and ODP is that very high sedimentation rate sections have been recovered using the APC, which provide high-resolution records of geomagnetic field behavior over scales ranging from polarity history to reversal transitions. Three examples of such records are shown in Figure 1. Note the high sedimentation rates in these sections; it is not uncommon to find a $50 \mathrm{~m}$ thick Brunhes chronozone corresponding to sedimentation rates exceeding $60 \mathrm{~m} / \mathrm{m}$.y. Such high- resolution records, together with nearly continuous (2-cm sampling interval) pass-through measurements, provide important insights into the global nature of short-duration

\section{Category 3}

\section{Site 722, Owen Ridge}

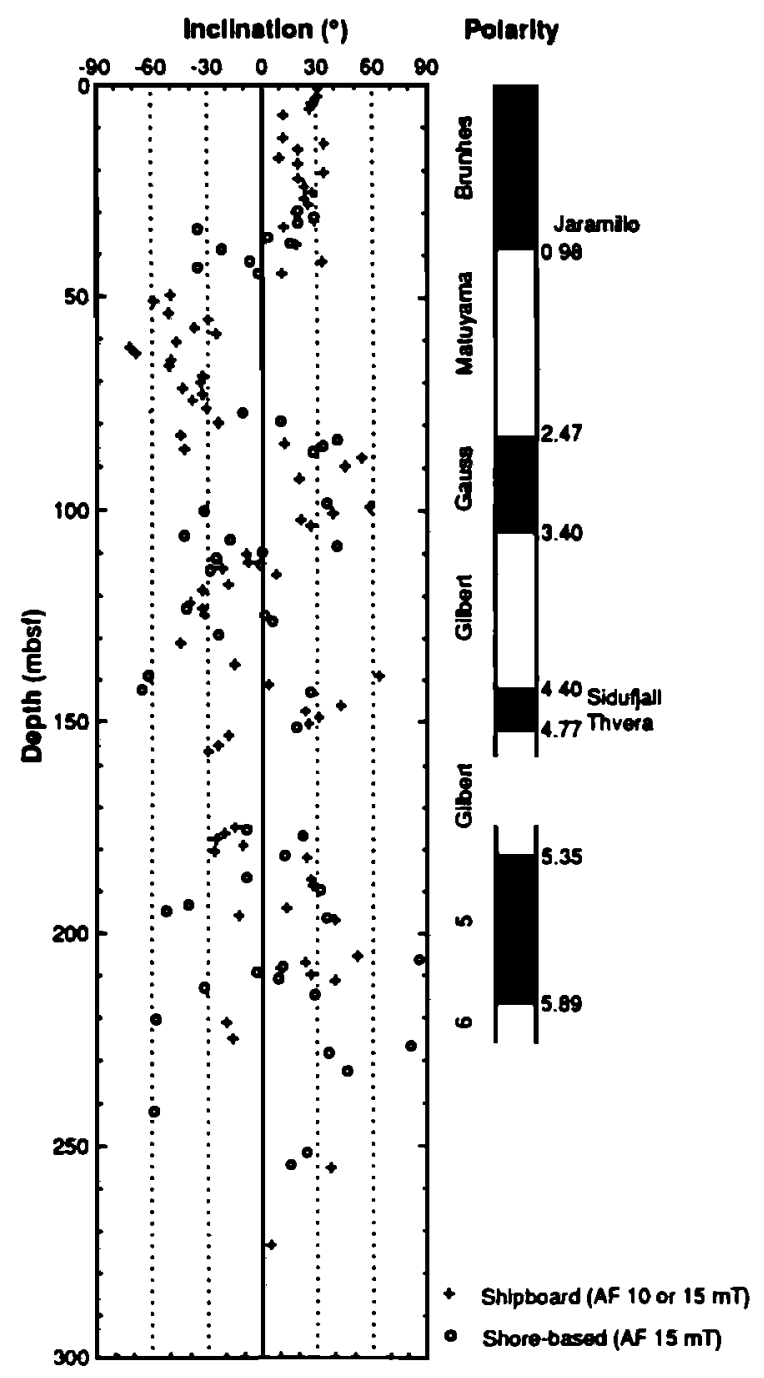

Figure 2. An example of a category 3 record obtained from Site 722 located on the Owen Ridge. In spite of considerable scatter evident in the magnetization directions, the directions can be interpreted in terms of polarity and correlated with the time scale. 
phenomena such as excursions. Although a number of excursions within the Brunhes have been documented in lavas and lake sediments, an examination of the high-resolution polarity records obtained from DSDP and ODP indicates that these phenomena are not observed on a global scale in deepsea sediments. Therefore, while these features may provide important insights into the workings of the geomagnetic field, they are not effective tools for correlation in deep-sea sediments.

Much can also be learned from examining the sites where quality records were not obtained. It is useful to consider the factors that affect these records separately as extrinsic and intrinsic factors. The extrinsic factors are those which do not originate in the innerent propenues of ule sediments but are usually problems originating from the drilling process. Examples of these problems include poor core recovery, core orientation, and remagnetizations resulting from exposure to strong magnetic fields encountered in core barrels and the bottom hole assembly (BHA). These extrinsic factors are particularly important to take note of because these are problems that can be remedied for future drilling. Intrinsic factors originate in the inherent properties of the sediments themselves and by separating these types of factors we stand to increase greatly our understanding of sediment magnetization.

\section{Extrinsic Factors}

Problems with core recovery that produce both obvious and more subtle gaps in the stratigraphic record can be effectively reduced using real time, shipboard core-to-core correlations and by coring multiple holes at a site. Difficulties with core orientation have had serious effects on several legs which drilled in equatorial regions. As discussed in detail in the workshop report, many of the problems with core orientation result directly from drilling operation procedures. The shipboard paleomagnetist and co-chief scientists must recognize the need to monitor closely the core orientation process.

A more difficult problem is the common occurrence of core barrel remagnetization. It has been clearly demonstrated that some of the core barrels have strong internal magnetic fields which in some sediment lithologies are capable of overprinting the original remanent magnetization. In many cases this overprint makes it impossible to retrieve any useful magnetic polarity information from the sediments. The overprint often is identified as a pervasive, radial magnetization, in which the declination is always directed from the center of the core outward usually with some additional vertical component. This type of magnetization is most readily observed, and is most detrimental to the paleomagnetic record, at equatorial or low latitude sites [Schneider and Kent, 1990]; however, it has also been detected at higher latitudes [Hailwood and Clement, 1991a]. This type of remagnetization evidently caused the failure to obtain a magnetostratigraphic record from the Ceara Rise, a leg where a magnetostratigraphic time framework was an important scientific objective. This type of remagnetization is most likely to affect sediments which exhibit a large, low-coercivity component with a relatively weak but stable characteristic remanent magnetization. Because of the large, soft component, a magnetization acquired by exposure to a locally strong magnetic field may completely swamp the characteristic remanence. Attempts to demagnetize the core barrel have been attempted but with only moderate success [Schneider and Kent, 1990]. Using nonmagnetic core barrels, possibly made out of stainless steel, may be the only way to ensure useful paleomagnetic results from the many sediments capable of providing useful records which are now remagnetized during the drilling process.

\section{Intrinsic Factors}

There are two major working hypotheses for the origin of the magnetic carrier in deep-sea sediments. The first of these is that the magnetic carrier is lithogenic, small grains of magnetic oxides transported by ice, water, or wind from terrigenous sources to the deep sea. The second of these is that the magnetic material is biogenic, produced in place by magnetotactic bacteria or other organisms that yield magnetite. Fossil magnetosomes have been found in deep-sea sediments and they provide an explanation for the source of magnetically stable magnetite [Chang and Kirschvink, 1989; Petersen et al., 1986]. As described below, either source can account for a remanent magnetism that is initially present in most sediments. A more important control on the fidelity of the paleomagnetic record, however, is likely to be the degree of reduction diagenesis, or in some cases low-temperature oxidation of the original magnetic oxides.

A common intrinsic factor that affects the paleomagnetic signal is the dissolution of magnetic oxides during reduction diagenesis. Early experience in magnetostratigraphy of carbonate rich deep-sea sediments showed a correlation with the disappearance of a measurable paleomagnetic signal with the first downhole appearance of authigenic pyrite in the sediments. Later workers identified and quantified the processes at work in the reduction of the iron oxides that carry the stable magnetic remanence [Canfield and Berner, 1985; Karlin and Levi, 1985; Musgrave et al. , 1993; Tarduno, 1994]. Musgrave et al, [1993] and Tarduno [1994] demonstrated that the depth below the sea floor at which the remanence intensity decreased was related to the amount of organic matter delivered to the sea floor which is a function of water depth.

In some cases it appears that the reduction diagenesis has completely erased the paleomagnetic signal, and therefore sites with an originally high input of organic matter are poor targets for paleomagnetic study. However, there are a few cases where the intensity is observed to increase again below the zone of reduction diagenesis and a polarity record is obtained which appears to be original. This may indicate that the supply of organic matter to the site varied with time, meaning that the reduction diagenesis has proceeded to different extents in different portions of the section [Tarduno, 1994]. It also may mean that other factors, such as overall sediment lithology, had a role in affecting the reduction diagenesis. For example, in the North Atlantic Ocean, as documented in the DSDP Leg 94 sites, the Pliocene sediments are carbonate rich and commonly exhibit very low intensities, and the presence of pyrite indicates that these sediments have undergone reduction diagenesis. However, a stable polarity zonation is observed below this interval, suggesting that these older sediments did not experience the reduction diagenesis to the 

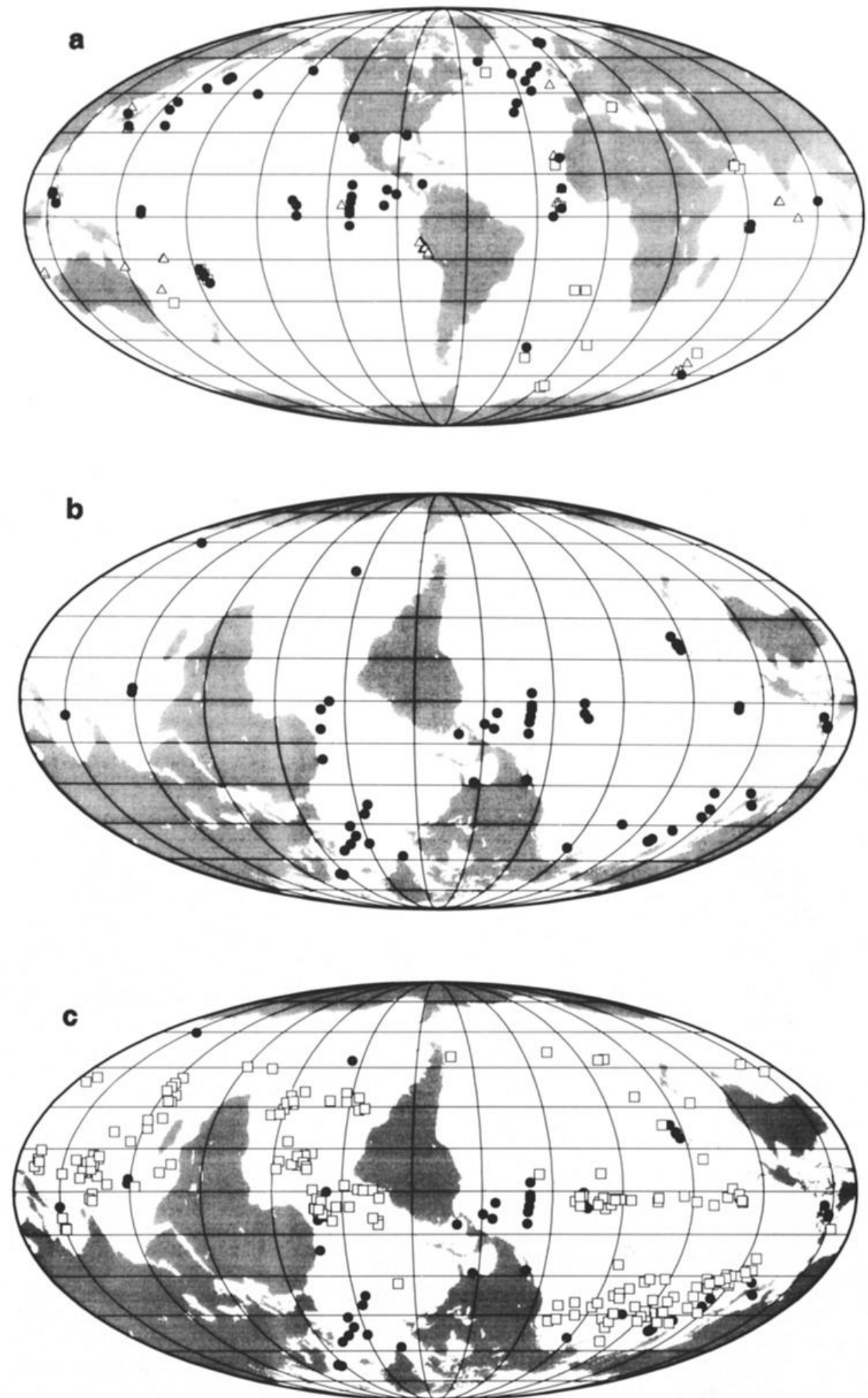

Figure 3. The distributions of DSDP and ODP advanced hydraulic piston corer (APC) sites (a) yielding category 1 through 4 records and (b) those yielding category 1 and 2 sites. Category 1 and 2 sites are represented by solid circles,category 3 sites are represented by open squares, and category 4 sites are represented by open triangles. (c) The distribution of DSDP and ODP APC sites yielding category 1 and 2 sites (solid circles) and the locations of piston cores from the Lamont-Doherty Earth Observatory collection which produced category 1 records (open squares). 
same extent as the younger sediments [Clement and Robinson, 1985]

Reduction diagenesis may be common in most deep-sea sediments and not be necessarily always deleterious. If it occurs to only a moderate degree, reduction diagenesis could even be responsible for a more stable remanent magnetism by the selective removal of ultrafine grained, hence magnetically less stable remanence carriers [Tarduno, 1995]. Only in very slowly deposited sediments such as red clays [Kent and Lowrie, 1974] is there evidence for early oxidation of magnetic minerals, a physical-chemical change which can also result in unstable magnetizations [Henshaw and Merrill, 1980].

\section{Distribution of Sites}

In order to examine further the factors that affect the quality of the magnetostratigraphic records, we plotted the site locations of the ranked magnetostratigraphic records. The distribution of category 1-4 sites is shown in Figure 3a. This distribution represents the APC sites that exhibit measurable magnetization. More insight into what affects the distribution of useful magnetostratigraphic records may be obtained by examining the distribution of the best quality records (category 1 and 2, Figure 3b).

The number of category 1 and 2 sites is relatively small and does not provide a large enough number of sites to analyze the distribution. For this reason we included the distribution of piston core results primarily from the Lamont-Doherty Earth Observatory collection [Schneider and Kent, 1990]. These results from these piston cores meet our criteria for category 1 records, although they are limited to lower sedimentation rate sediments (in order for reversals to be observed in a conventional piston core length). The combined distribution of category 1 and 2 HPC/APC sites together with the Lamont piston core localities is plotted in Figure 3c.

The distribution of the high-quality magnetostratigraphic results is plotted on a map of deep-sea sediment lithology for comparison of the paleomagnetic data and the sediment composition (Plate 1). The observed distribution of category 1 and 2 records can be broken down into two types of regions. The first are regions of high terrigenous input. This includes the high latitudes, particularly in the Pacific and the North Atlantic, and to a lesser degree the Southern Ocean, where there is an abundant supply of terrigenous material delivered to the sites primarily as ice-rafted debris. Likewise, the Indian Ocean receives a tremendous supply of terrigenous material from the Himalayan Mountains, and the equatorial Atlantic receives abundant aeolian input from Africa. The observed concentration of category 1-2 records in these areas tends to confirm the interpretation that detrital material is critically important to the paleomagnetic recording process.

The one region that runs counter to this interpretation is the equatorial Pacific. This region receives very little input of terrigenous material, and yet a number of important magnetostratigraphic records have been obtained from this region. The alternative interpretation is that biogenic material is an important contributor to the paleomagnetic record, and if so, it will tend to be more important in areas where there is enough organic matter delivered to the sea floor in order to support the magnetotactic bacteria which generate the biogenic magnetic material.
To examine this idea further, we plotted the distribution of category 1 and 2 sites and the Lamont piston core sites on a global map of photosynthesis in the modern ocean (Plate 2). The photosynthesis map shows the distribution of productivity in the modern ocean and provides a first order indication of where we would expect increased amounts of organic matter being delivered to the seafloor. An excellent agreement is observed indicating that some, but not too much, organic matter is required to produce a high-quality magnetostratigraphic record. This would be expected if the bottom dwelling organisms that produce biogenic magnetite require a supply of organic material to survive. Another possible factor in this is that the amount of silica may be an important factor in affecting the quality. Silica content may affect reduction diagenesis, leading to less dissolution of the magnetic oxides and greater preservation of the paleomagnetic record. Sediments accumulating beneath regions of high biological productivity have greater concentrations of silica, hence the possible correlation.

This distribution may be somewhat biased as most of these sites were cored for paleoceanographic objectives, and therefore sites were not drilled into regions, such as the red clay zones in the Pacific, where it is clear that no reasonable fossil record will be obtained. Useful magnetic records have been obtained at least from the upper intervals of cores taken in red clay sediment, indicating that terrigenous input is more important than biogenic magnetite. Therefore it is probably not too wise to draw firm conclusions from these distributions, because the sampling distribution is uneven. However, based on the comparisons of the distribution of quality records with surface sediment lithology and the surface productivity maps, a reasonable correlation between the distribution of high-quality magnetostratigraphic records and surface biological productivity is observed.

\section{Summary and Recommendations}

The distribution of magnetostratigraphic records obtained by piston-coring deep-sea sediments provides intriguing hints as to the variables that are important in affecting the quality of the polarity record. Further insights, however, will need to be gained from studies at individual sites with attention given to the possible factors outlined here. In order to move toward a more quantitative assessment of these factors, it is important that future workers report not just the downhole variations in magnetization directions, intensities, and rock magnetic properties but also the means of these values along with the observed dispersion about the means. In sections where the magnetic properties vary considerably, sorting these variations into lithologic or rock magnetic units which exhibit internally consistent properties will provide a more clear picture of the variations. Summarizing the data in these ways, although not always of direct relevance to the specific individual leg objectives, will make direct comparisons of results from other sites and other regions much more straightforward.

It is also important that steps be taken to reduce the effects of the extrinsic factors discussed here. This will not only improve the quality of magnetostratigraphic data, it will also make the underlying intrinsic factors affecting the recording fidelity of sediments more clearly evident. 


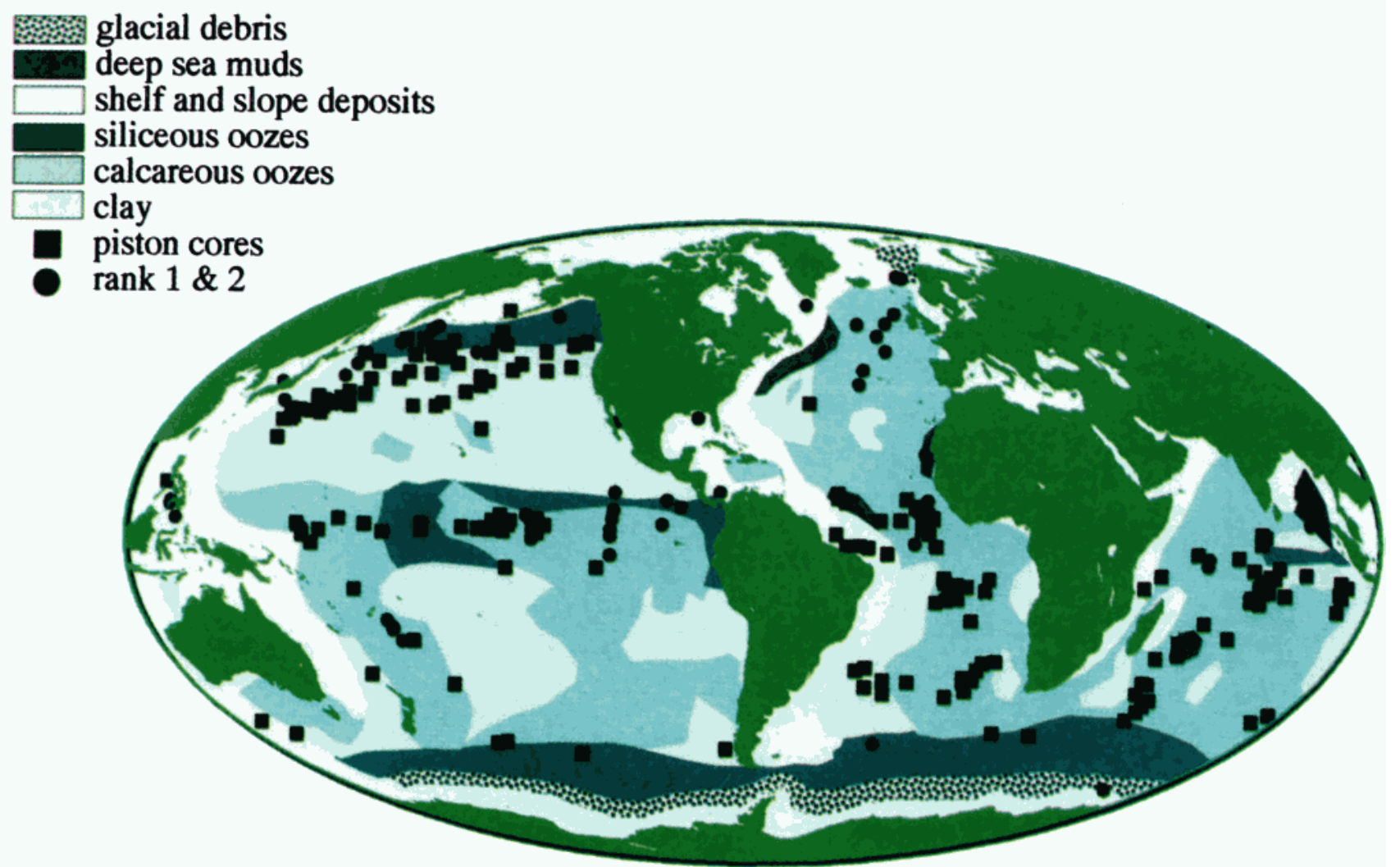

Plate 1. The distribution of DSDP and ODP APC sites yielding category 1 and 2 sites (circles) and the locations of piston cores from the Lamont-Doherty Earth Observatory collection which produced category 1 records (squares) plotted on a map of surface sediment lithology (modified after Berger, [1974]). A good correlation exists between the location of good quality magnetostratigraphic records and sediments rich in terrigenous input.

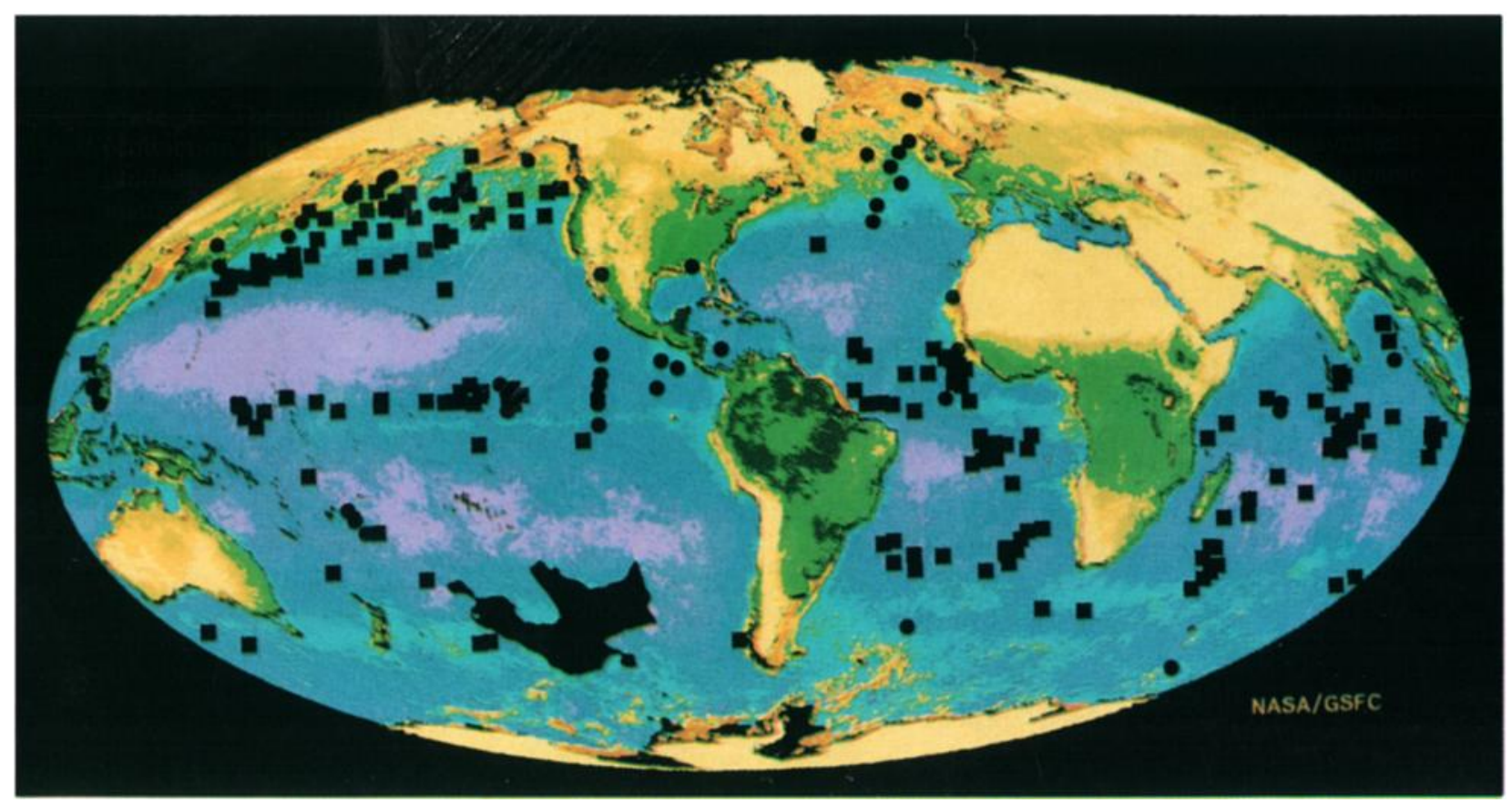

Plate 2. The distribution of category 1 and 2 sites and piston cores plotted on a map of photosynthetic production in the modern ocean (courtesy of NASA/Goddard Space Flight Center). The photosynthetic production (violet (low) to orange (high)) provides a rough proxy for the distribution of the supply of organic matter to the seafloor. 
Acknowledgments.. Zhong Yang assisted with the data synthesis presented here. We also thank the Ocean Drilling Program for providing coring data. This work was supported by a grant from the Joint Oceanographic Institutions, Inc. and the U. S. Science Advisory Committee.

\section{References}

Abrahamsen, N., and W. W. Sager, Cobb Mountain geomagnetic polarity even and transition in three deep-sea sediment cores from the Lau Basin, edited by J. Hawkins et al., Proc. Ocean Drill. Program Sci. Results, 135, 737-762, 1994.

Ali, J. R., R. B. Haston, and L. Stokking, Magnetostratigraphy of sites 782, 783, 784, and 786, Izu-Bonin outer forearc, western Pacific, in Freyer, P., Pearce, J. A., Stokking, L., et al., Proc. Ocean Drill. Program Sci. Results, 122, 547-560, 1992.

Barton, C. E., Paleomagnetic and mineral magnetic record of sediments from the Queensland Trough: Results for Leg 133, Hole 823A, edited by J. A. McKenzie et al., Proc. Ocean Drill. Program Sci. Results, 133, 563-571, 1993.

Barton, C. E., and J. Bloemendal, Paleomagnetism of sediments collected during Leg 90, Southwest Pacific, edited by J. P. Kennett et al., Initial Rep. Deep Sea Drilling Proj., 90, 1273-1316, 1986.

Barton, C. E., S. K. Omarzai, I. Alexander, F. Peerdeman, and D. McNeill, Magnetic stratigraphy and characterization of sediments from the northeast margin of Australia and their relationship to environmental change during the Quaternary, edited by J. A. McKenzie et al., Proc. Ocean Drill. Program Sci. Results, 133, 723 747, 1993.

Becker, K. et al., Proceedings of the Ocean Drill. Program, Initial Reports., vol. 111: Ocean Drill. Program, College Station, Tex., 1988.

Berger, W. H., Sediment cover of the sea floor, in The Geology of Continental Margins, edited by C. A. Burk and C. L. Drake, pp. 213243, Springer, New York, 1974.

Bleil, U., The magnetostratigraphy of northwest Pacific sediments, Deep Sea Drilling Project Leg 86, edited by G. R. Heath et al., Initial. Rep. Deep Sea Drill. Proj., 86, 441-458, 1986.

Bleil, U., Magnetostratigraphy of Neogene and Quaternary sediment series from the Norwegian Se: Ocean Drilling Program, Leg 104, edited by 0 . Eldholm et al., Proc. Ocean Drill. Program Sci. Results, 104, 829-901, 1989.

Canfield, D. E., and R. A. Berner, Dissolution and pyritization of magnetite in anoxic sediments, Geochim. Cosmochim. Acta., 51, 645-659, 1985.

Chang, S. R. and J. L. Kirschvink, Magnetofossils, the magnetization of sediments, and the evolution of magnetite biomineralization, Annu. Rev. Earth. Planet. Sci., 17, 169-195, 1989.

Channell, J. E.T., Torii, M. and T. Hawthorne, Magnetostratigraphy of sediments recovered at Sites $640,651,652$, and 654 (Leg 107 , Tyrrhenian Sea), edited by K. A. Kastens et al., Proc. Ocean Drill. Program Sci. Results, 107, 335-346, 1990

Cisowski, S. M. and M. Koyama, Detailed record of the BrunhesMatuyama polarity reversal in high sedimentation rate marine sediments from the Izu-Bonin arc, edited by B.Taylor et al., Proc. Ocean Drill. Program Sci. Results, 126, 341-352, 1992.

Clement, B. M., and F. Robinson, The magnetostratigraphy of Leg 94 Sediments, edited by W. F. Ruddiman et al., Initial Rep. Deep Sea Drill. Proj., 94, 635-649, 1985.

Clement, B. M., and E. Hailwood, The magnetostratigraphy of Site 701 and 702 sediments, ODP Leg 114, edited by P. Ciesielski et al., Proc. Ocean Drill. Program Sci. Results, 114, 359-366, 1991.

Clement, B. M., F. Hall, and R. Jarrard, The magnetostratigraphy of Leg 105 sediments, edited by S. P. Srivastava et al., Proc. Ocean Drill. Program Sci. Results, 105, 583-595, 1989.

Gallet, Y., Gee, J., Tauxe, L. and J. Tarduno, Paleomagnetic analyses of short normal polarity magnetic anomalies in the Matuyama Chron, edited by W. H. Berger et al., Proc. Ocean Drill. Program Sci. Results, 130, 547-559, 1993.

Hailwood, E. and B. M. Clement, The magnetostratigraphy of ODP Sites 699 and 700, East Georgia Basin, edited by P. Ciesielski et al., Proc. Ocean Drill. Program Sci. Results, 114, 337-358, 1991a.
Hailwood, E., and B. M. Clement, The magnetostratigraphy of ODP Sites 703 and 704, Meteor Rise, Southeastem South Atlantic, edited by P. Ciesielski et al., Proc. Ocean Drill. Program Sci. Results, 114, 367-386, 1991b.

Hall, S. A., and W. W. Sager, Paleomagnetic and rock magnetic properties of sediments samples from ODP Leg 116, Central Indian Ocean, edited by J. R. Cochran et al., Proc. Ocean Drill. Program Sci. Results, 116, 337-344, 1990.

Hamano, Y., K. A. O. Krumsiek, L. Vigliotti, and J. M.Wippern, Pliocene-Pleistocene magnetostratigraphy of sediment cores from the Japan Sea, edited by K. Tamaki et al., Proc. Ocean Drill. Program Sci. Results, 127/128 Pt.2, 969-972, 1992.

Hayashida, A., and J. Bloemendal, Magnetostratigraphy of ODP Leg 117 sediments from the Owen Ridge and the Oman Margin, western Arabian Sea, edited by W. L. Prell, et al., Proc. Ocean Drill. Program Sci. Results, 117, 161-179, 1991.

Heider, F., B. Leitner, and H. Inokuchi, High southern latitude magnetostratigraphy and rock magnetic properties of sediments from Sites 747, 749, and 751, edited by S. W. Wiseet al., Proc. Ocean Drill. Program Sci. Results, 120, 225-245, 1992.

Henshaw, P. C., and R. T. Merrill, Magnetic and chemical changes in marine sediments: Rev. Geophys., 18, 483-504, 1980.

Hounslow, M. W., P. A. Bootes, and G. Whyman, Remanent magnetization of sediments undergoing deformation in the Barbados Accretionary Prism: ODP Leg 110, edited by J. C. Moore. et al., Proc. Ocean Drill. Program Sci. Results, 110, 379-391, 1990.

Hsu, V., H. Shibuya, and D. L. Merrill, Paleomagnetic study of deepsea sediments from the Cagayan Ridge in the Sulu Sea: Results of Leg 124, edited by E. A. Silver et al., Proc. Ocean Drill. Program Sci. Results, 124, 511-518, 1991.

Inokuchi, H., and F. Heider, Magnetostratigraphy of sediments from Sites 748 and 750, Leg 120, edited by S. W. Wise et al, Proc. Ocean Drill. Program Sci. Results, 120, 247-252, 1992.

Karlin, R. and S. Levi, Paleomagnetism of laminated sediments from the Guaymas Basin, Gulf of California, Deep Sea Drilling Project site 480, edited by Curray, J. R. et al., Initial Rep. Deep Sea Drill. Proj., 64, 1255-1258, 1982.

Karlin, R., and S. Levi, Geochemical and sedimentological control of the magnetic properties of hemipelagic sediments, J. Geophys. Res., 90, 10373-10392, 1985.

Keating, B. H., and H.Sakai, Magnetostratigraphic studies of sediments from site 744, southem Kerguelen Plateau, edited by J. Barron et al., Proc. Ocean Drill. Program Sci. Results, 119, 771-794, 1991.

Kent, D. V. and W. Lowrie, Origin of magnetic instability in sediment cores from the central North Pacific: J. Geophys. Res., 79, 2987$3000,1974$.

Kent, D. V., and D. J. Spariosu, Magnetostratigraphy of equatorial Pacific site 503 hydraulic piston cores, edited by W. Prell et al., Initial Rep. Deep Sea Drill. Proj. 68, 435-440. 1982a.

Kent, D. V., and D. J. Spariosu, Magnetostratigraphy of Caribbean site 502 hydraulic piston cores, edited by W. Prell et al., Initial Rep. Deep Sea Drill. Proj. 68, 419-433, 1982 b.

Krumsiek, K., and D. G. Roberts, Paleomagnetics of Tertiary sediments from the southwest Rockall Plateau, DSDP Leg 81, edited by D. G. Roberts et al., Initial Rep. Deep Sea Drill. Proj. 81, 837-851, 1984.

Mayer, L. et al., Proceedings of the Ocean Drilling Program Initial Reports., vol. 138, 1992.

McNeill, D. F., T. S. Guyomard, and T. B. Hawthorne, Magnetostratigraphy and the nature of magnetic remenance in platform/periplatform carbonates, Queensland Plateau, Australia, edited by McKenzie et al., Proc. Ocean Drill. Program Sci. Results, 133, 573-614, 1993.

Musgrave, R. J., M. L. Delaney, R. Stax, and J. A. Tarduno, Magnetic diagenesis, organic input, interstitial water chemistry, and the paleomagnetic record of the carbonate sequence on the OntongJava Plateau, Proc. Ocean Drill. Program Sci. Results, 130, 527-330, 1993.

Pearce, J. et al., Proceedings of the Ocean Drilling Program Initial Reports., vol. 121, 359-458, 1989.

Petersen, N., R. von Dobeneck, and H. Vali, Fossil bacterial magnetite in deep-sea sediments from the South Atlantic Ocean, Nature, 320, 611-615, 1986. 
Rea, D. K., et al., Proceedings of the Ocean Drilling Program Initial Reports., vol. 145, 1993.

Sager, W. W., Paleomagnetism of Ocean Drilling Program Leg 101 sediments: magnetostratigraphy, magnetic diagenesis and paleolatitudes, edited by J. A. Austin et al., Proc. Ocean Drill. Program Sci. Results, 101, 327-360, 1988.

Sakai, H., and B. H. Keating, Paleomagnetism of Leg 119 - Holes 737A, 738C, 742A, 745B, and 746A, edited by J . Barron et al., Proc. Ocean Drill. Program Sci. Results, 119, 751-770, 1991.

Salloway, J. C., Paleomagnetism of sediments from Deep Sea Drilling Project Leg 71, edited by W. J. Ludwig et al., Initial Rep. Deep Sea Drill. Proj., 71, 1073-1091, 1984.

Schneider, D. A., and D. V. Kent, Paleomagnetism of Leg 115 sediments: Implications for Neogene magneto-stratigraphy and paleolatitude of the Reunion Hotspot, edited by R. A. Duncan et al., Proc. Ocean Drill. Program Sci. Results, 115, 717-736, 1990.

Schonharting, G., Sharma, P. V. and S. Kentved, Magnetic polarity transition zones at the Brunhes/Matuyama and upper Olduvai boundaries: Preliminary results from Ocean Drill. Program Sci. Results Leg 104, edited by O. Eldholm et al., Proc. Ocean Drill. Program Sci. Results, 104, 903-910, 1989.

Speil, V., Cenozoic magnetostratigraphy of Leg 113 Drill Sites, Maud Rise, Weddell Sea, Antarctica, edited by P. F. Barker et al., Proc. Ocean Drill. Program Sci. Results, 113, 261-315, 1990.

Suess, E. et al., Proceedings of the Ocean Drilling Program Initial Reports., vol. Il2, 1988.

Tang, C., Paleomagnetism of Cenozoic sediments in holes 762B and 763A, Central Exmouth Plateau, northwest Australia, edited by U. von Rad et al., Proc. Ocean Drill. Program Sci. Results, 122, 717733, 1992.

Tarduno, J. A., Temporal trends of magnetic dissolution in the pelagic realm: Gauging paleoproductivity?, Earth Planet Sci. Lett., 123, 3948, 1994.

Tarduno, J. A., Superparamagnetism and reduction diagenesis in pelagic sediments: Enhancement or depletion?, Geophys. Res. Lett., 22, 1337-1340, 1995.

Tauxe, L, P. Tucker, N. Petersen, and J. L. LaBrecque, Magnetostratigraphy of Leg 73 sediments, edited by K. L. Hsu et al., Initial Rep. Deep Sea Drill. Proj., 73, 609-621, 1984.

Tauxe, L., Valet, J.-P., and J. Bloemendal, Magnetostratigraphy of Leg 108 Hydraulic Piston Cores, edited by W. Ruddiman et al., Proc. Ocean Drill. Program Sci. Results, 108, 429-439., 1989.

Townsend, H., The paleomagnetism of sediments acquired from the Goban Spur on Deep Sea Drilling Project Let 80, edited by P. C. de Graciansky et al., Initial Rep. Deep Sea Drill. Proj. 80, 389-414, 1985.

Valet, J.-P., L.Tauxe, and J. Bloemendal, The Matuyama-Brunhes geomagnetic reversal from two deep-sea cores of the Eastern Equatorial Atlantic, edited by W. Ruddiman et al., Proc. Ocean Drill. Program Sci. Results, 108, 441-452, 1989.

Weinreich, N., and F. Theyer, Paleomagnetism of Deep Sea Drilling Project Leg 85 sediments: Neogene magnetostratigraphy and tectonic history of the Central Equatorial Pacific, edited by L. Mayer et al., Initial Rep. Deep Sea Drill. Proj. 85, 849-901, 1985.

Zhao, X., R. Roperch, and L. B. Stokking, Magnetostratigraphy of the North Aoba Basin, edited by H. C. Greene et al., Proc. Ocean Drill. Program Sci. Results, 134, 457-474, 1994.

B. M. Clement, Department of Geology, Florida International University, Miami, FL, 33199. (e-mail: clementB @ servms.fiu.edu) 10964 .

D. V. Kent, Lamont-Doherty Earth Observatory, Palisades, NY,

N. D. Opdyke, Department of Geology, 137 Turulington Hall, University of Florida, Gainesville, FL, 32611.

(Received August 11, 1995; revised November 9, 1995; accepted November 9,1995 ) 